\title{
BACTERIOLOGICAL PROFILE OF SELECTED FISH SPECIES AND WATER SAMPLE FROM OTUOCHA RIVER ANAMBRA STATE
}

\author{
Amuneke, K.E., Igbodiegwu, G.C., Okeke, P. A., and Adibe, A.C. \\ Department of Fisheries and Aquaculture, Nnamdi Azikiwe University Awka \\ Corresponding author: ke.amuneke@unizik.edu.ng
}

\begin{abstract}
Attempt to ensure fish food security is a continuous process and food safety is a global concern for consumers and food industry. Fish is an important source of healthy and cheap source of animal protein that among its numerous benefit fish is widely acceptable, across socio-economic, age and religious barrier. However, supply of contaminated free fish is desirable to ensure safe consumption and a healthy consumer public: The objective of the study is to provide baseline information on the microbial quality of Otuocha river, hence establish the microbial quality of fish caught in Otuocha river. Five fish species (Aruis gigas, Bagrus bayad, Schilbe mystus, Chrysichthys nigroditatus and Protopterus annectens) and water sample were taken from Otuocha fish landing site and river respectively and transported to laboratory. The fish samples were cleaned with sterile distilled water and $1 \mathrm{~g}$ of skin, gills, intestine cut aseptically and labelled along with water sample before microbial analysis following standard method. The result obtained in water and fish samples showed high microbial load in Otuocha river and was attributed to anthropogenic sources. Nine different bacteria were isolated in fish samples while seven were isolated in water sample. The study concluded that Otuocha river has high microbial load, hence recommend that fish from Otuocha river should be properly cooked/smoked before consumption and sanitary standard of Otuocha river and its environs be improved while public enlightenment on waste disposal be undertaken.
\end{abstract}

Key words: Microbial load, fish, water, Otuocha River

https://doi.org/10.4314/jafs.v18i1.2

\section{INTRODUCTION}

Generally, attempt to ensure fish food security is a continuous process and food safety has been a major global concern for the consumers and those in the food service industry (Jacxsense et al., 2009). Fish and fisheries products have become an increasing important source of protein and other elements necessary for balanced nutrition and maintenance of healthy body (FAO, 2012). It also constitutes the cheapest source of animal protein in Africa (Clucas and Ward, 1996). Fish have always been an important component of human food even for the poorest of the poor, particularly around lakes, rivers, deltas, floodplains, coastal areas and particularly in Island. In Nigeria, fish is the preferred source of much desired animal protein compared to other sources because it is comparatively cheaper and highly acceptable (Adebayo-Tayo et al., 2012). Fish consumption accounts for about $35 \%-40 \%$ of animal protein intake in Nigeria (Adedeji and Ibrahim, 2013). Fish provides faster and fresher Journal of the Faculty of Agriculture and Veterinary Medicine, Imo State University Owerri website: www ajol.info/index.php/jafs

Open Access article distributed under the terms of the Creative Commons License CC BY-NC 
Volume 18, Number 1, April, 2020 pp $11-26$.

\& Adibe, A.C.

access to one of the healthiest and cheapest sources of animal protein. Hence, fish are widely acceptable on the menu card and form a much-cherished delicacy that cuts across socioeconomic, age, religious and educational barriers (Adebayo-Tayo et al., 2008). As a major source of food, fish provide livelihood for millions of people along the value-chain. It is a most important animal dietary protein available in the world, and represents about $14 \%$ of all animal protein on a global basis (Abolagba and Melle, 2008). FAO (2002) submitted that most of the world population (56\%) derive at least $20 \%$ of its animal protein intake from fish. Fish is regarded a healthier meat option due to the high content of long chain poly unsaturated fatty acids (LUPUFA'S) which are associated with improving health and preventing disease of old age (Kabaherda et al., 2009).

However, supply of very minimal contaminated fish and proper hygienic handling and processing is desirable to ensure safe consumption of the consumer public. This is because consumption of fish may sometimes cause disease due to infection (FDA, 2011) which had been established in many of the food-borne illnesses and intoxication (Adedeji et al., 2011). Some of these infections have been specially associated with pathogens which are resistant to antibiotics (Adebayo-Tayo et al., 2012a). Aquatic systems that harbour the fish may be the source of contaminants due to indiscriminate deposition of faecal material and other environmental wastes discharged into natural water (Adedeji et al., 2011). Thus, pollution can significantly affect the quality of fish because the fish species inhabiting polluted waters have already compromised their original healthy status (Adeyemo, 2003). Fish are carriers of microbes and other health hazards (Yagoub 2009, Adebayo et al., 2012) and may harbour pathogens on or inside its body after exposure to contaminated water or food (Aliyu et al.,

2016). Therefore, the presence or
absence of pathogens in fish product is a function of the harvest environment, sanitary conditi ons, and practices associated with equipment and personnel in the processing environment $(\mathrm{F}$ AO, 2003).Water bodies are contaminated through runoffs, sewage, agricultural wastes, and waste produce by increase human activities; these are usually high in organic matter nutrient. Hence, they could cause increase in the microbial flora of the water bodies, thereby resulting in high heterotrophic bacteria counts. The type of microorganism found associated with fish depends on the aquatic habitat of fish and are known to be affected by certain factors like salinity level and bacterial load of the habitat (Diler et al., 2000). Adebayo-Tayo et al. (2012) reported upon quality assessment for tropical freshwater fish species that differences exist based on location and time. In some developing nations, there is poor waste disposal which ultimately leads to pollution of bodies of water as the last point of discharge. Expectedly, the fish in such bodies of water become contaminated and a source of human infection. Since, changes in microbial population are one of the indices for assessing fish quality (Sallam, 2007), contamination concern has been on high loads of microorganisms like Salmonella species, Staphylococcus aureus, Pseudomonas aeruginosa and Escherichia coli (Okonko et al., 2008). Though in fish, non-indigenous pathogens may not be pathogenic but could cause infection if ingested by man (Aliyu et al., 2016). Few infectious agents in fish are able to infect humans, some exceptions exist that may result in fatalities (Adebayo et al., 2012). However, the greatest risk to human health is due to the consumption of raw or insufficiently

Journal of the Faculty of Agriculture and Veterinary Medicine, Imo State University Owerri website: www ajol.info/index.php/jafs

Open Access article distributed under the terms of the Creative Commons License CC BY-NC 
Journal of Agriculture and Food Sciences

Amuneke, K.E., Igbodiegwu, G.C., Okeke, P. A.,

Volume 18, Number 1, April, 2020 pp $11-26$

\& Adibe, A.C.

processed fish and fish products (Yagoub 2009, Adebayo et al., 2012, Adedeji et al., 2012). Novotny et al. (2004) had reported that human infections caused by pathogens transmitted from fish or the aquatic environment is quite common and depend on the season, patient's contact with fish and related environment, dietary habits and the immune system status of the exposed individual.

There is dearth of information on the public health importance associated with fishes caught and sold at Otuocha river in South-East Nigeria. Considering the level of pollution and the influx of fish consumers to Otuocha river, there is an urgent need to establish the microbial quality of fish caught in Otuocha river. The use of Otuocha river is prompted by the role the river plays in the supply of fish to Anambraians and regular use of the river for domestic purposes. However, Otuocha river receive a lot of effluent due to anthropogenic activities around the river; hence there is need to ascertain the microbial status of the river. Therefore, the objective of this study is to examine selected commercially important fish species of the Otuocha river for incidence and intensity of microbial load. Hence, this study will help to provide baseline information on biological pollution status of Otuocha river.

\section{MATERIALS AND METHODS}

Otuocha river: Otuocha river is located in Umueri, a major community of Umuobanam clan in Anambra East Local Government Area of Anambra State. Otuocha River lies on latitude 633'33' $\mathrm{N}$ and longitude 6 ${ }^{\circ} .85^{\prime} 12 \mathrm{E}$. It is a tributary of river Niger, on the north east by Ezu river and south east and south west by Akor River. Also close to the river is the Otuocha market which terminated in the river and Nigerian Marine Police, to manage and see to the activities carried out in Otuocha river.

Samples collection: One sample of live Aruis gigas, Bagrus bayad, Schilbe mystus, Chrysich ths nigroditatus and Protopterus annectens were collected from landing site of Otuocha river. The fish samples were transported in disinfected labelled jerry cans containing the river water, to the Laboratory of the Department of Microbiology and Brewery, Nnamdi Azikiwe University, Awka. Upon arrival the samples were cleaned with sterile distilled water and one gram of their skin, gill and intestine was cut aseptically, labelled appropriately (Aruis gigas: sample

A,

Bagrus bayad: sample B Schilbe mystus: sample C, Chrysichthys nigroditatus: D and Protopterus an nectens: E) for microbial analysis.

Water samples for microbiological analysis were collected in a sterile amber coloured glass bottle. The samples were collected by dipping the sample bottle into the river to a depth of 30 $\mathrm{cm}$ below water surface, opened, allowed to fill up with water and then corked while still under the water (APHA, 1985). The water was labelled, placed in iced box and transported to the Laboratory for microbial analysis.

Journal of the Faculty of Agriculture and Veterinary Medicine, Imo State University Owerri website: www ajol.info/index.php/jafs

Open Access article distributed under the terms of the Creative Commons License CC BY-NC 
Journal of Agriculture and Food Sciences

\section{Water sample analysis}

Total bacterial count: Ten-fold serial dilution of the water sample was done and appropriate dilutions were placed on Nutrient Agar plates and incubated for 24 hours. Thereafter, the developing colonies were counted and the Total bacterial count calculated thus:

$\operatorname{TBC}(\mathrm{CFU} / \mathrm{ml})=\frac{\mathrm{N}}{\mathrm{VD}}$

Where: $\mathrm{TBC}=$ Total bacterial count

$\mathrm{V}=$ Volume of inocula plated

$\mathrm{N}=$ Number of colonies, developing on plate, that were counted

$\mathrm{D}=$ Dilution factor +

$\mathrm{CFU} / \mathrm{ml}=$ Colony forming unit per millilitre

Determination of total coliform using membrane-filter technique: A $50 \mathrm{ml}$ water sample was filtered through a membrane filter which retains the bacteria found in the sample. The filters containing bacteria were placed on an absorbent pad saturated with lactose broth and incubated at $35{ }^{\circ} \mathrm{C}$ for $2 \mathrm{hrs}$. The filters were then transferred to an absorbent pad saturated with Eosin-methylene blue and MacConkey media and incubated for another $21 \mathrm{hrs}$ at $35^{\circ} \mathrm{C}$. Developing colonies were then counted under magnification and reported per $100 \mathrm{ml}$ of original sample. One in ten dilution of the water sample was prepared by transferring $5 \mathrm{ml}$ of the water sample into $45 \mathrm{ml}$ of sterile water contained in $100 \mathrm{ml}$ conical flask and filtered in the membrane filter apparatus. The calculations were thus:

$$
\text { No. of colonies per } 100 \mathrm{ml}=\frac{(\text { No. of colonies counted on plate })}{\text { Volume filtered }} \times 100
$$

Fish sample analysis: Different parts of fish (skin, gill and intestine) measuring $1 \mathrm{~g}$ each were cut and weighed out aseptically and introduced into $10 \mathrm{ml}$ of sterile peptone water in a test tube, it was properly shaken to homogenize the sample. A 10-fold serial dilution of each of the sample was carried out using peptone water as the diluents. Appropriate dilutions $\left(10^{-2}\right.$ and $10^{-3}$ ) of $0.1 \mathrm{ml}$ of the sample were plated in sterile plates of Nutrient agar (NA) plates, Eosin-methylene blue and MacConkey agar plates for the culture of bacteria. All culture plates were incubated at $37{ }^{\circ} \mathrm{C}$ aerobically for 24-48 hours. Developed colonies were counted to obtain total viable count and coliform counts respectively. Discrete colonies were obtained by sub culturing into agar plates and were subsequently identified using standard methods.

Characterization and Identification of Bacteria in water and fish sample: Identification of the bacterial isolates was accomplished by the observation of colonial characteristics, Gram reaction and biochemical tests (Cheesbrough, 1984). The characterization of the isolates was performed, by employing Gram staining reaction, Catalase test, Citrate test, Sugar fermentation test, Oxidase test, Coagulase test, Motility test, Indole test, Methyl Red and Voges proskauer test as described by Bergey and Holt (1994).

Journal of the Faculty of Agriculture and Veterinary Medicine, Imo State University Owerri website: www ajol.info/index.php/jafs

Open Access article distributed under the terms of the Creative Commons License CC BY-NC 
Journal of Agriculture and Food Sciences

\section{RESULT}

Bacteria enumeration of water sample: The result from the bacteria enumeration of water sample shows that the total bacteria count (TBC) of plate count $10^{-2}$ and $10^{-1}$ was higher $\left(1.42 \times 10^{5}\right.$ and $\left.1.72 \times 10^{4} \mathrm{cfu} / \mathrm{ml}\right)$ than the World health organisation (WHO) standard $(1.0 \mathrm{x}$ $\left.10^{3} \mathrm{cfu} / 100 \mathrm{ml}\right)$.

Biochemical characterization of isolates from water sample: Result of biochemical analysis shows that seven (7) isolates were identified which include, Escherichia coli, Enterobacter aerogenes, Pseudomonas aeruginosa and Klebsilella pneumonie, these are coliform bacteria while others include Staphylococcus aureus, Staphylococcus epidermids and Bacillus species as shown in table 3.

Bacteria enumeration of fish samples: The result of the bacterial enumeration of the five selected fish samples as shown in table 4 shows that the total bacteria load for serial dilution $10^{-2}$ ranged from $2.60 \times 10^{5}$ to $2.08 \times 10^{5} \mathrm{cfu} / \mathrm{g}$ for samples collected from the skin across different fish samples. But the skin of fish sample from sample D $\left(2.60 \times 10^{5} \mathrm{cfu} / \mathrm{g}\right)$, recorded high bacteria load compared to other samples collected from the skin across different fish samples in this order B, C, A, E respectively. The intestine recorded the highest microbial load in all the samples examined and the microbial load of the intestine ranged from $2.84 \times$ $10^{5} \mathrm{cfu} / \mathrm{g} \quad$ in sample $\mathrm{D}$ to $2.30 \times 10^{5} \mathrm{cfu} / \mathrm{g}$ in sample E. The gills recorded the least microbial load which ranged $\mathrm{fr}$ om $2.16 \times 10^{5} \mathrm{cfu} / \mathrm{g}$ in sample $\mathrm{C}$ to $1.28 \times 10^{5}$ in sample $\mathrm{B}$. The microbial load of the selected fish samples for serial dilution $10^{2}$ ranged from $2.84 \times 10^{5}$ to $1.28 \times 10^{5} \mathrm{cfu} / \mathrm{g}$. Similarly the result of the selected fish samples for serial dilution $10^{-3}$ follow the trend observed in serial dilution $10^{-2}$. In this case, the intestinal part of the fish recorded the highest microbial load that ranged from $2.04 \times 10^{6} \mathrm{cfu} / \mathrm{g}$ in sample D to $1.96 \times 10^{6} \mathrm{cfu} / \mathrm{g}$ in sample A. While microbial load of samples collected from Skin ranged from $1.96 \times 10^{6} \mathrm{cfu} / \mathrm{g}$ in sample D to $1.48 \times 10^{6}$ $\mathrm{cfu} / \mathrm{g}$ in sample A, and samples from the gills recorded the least microbial load among the samples. The microbial load in the fish sample ranged from $2.04 \times 10^{6} \mathrm{cfu} / \mathrm{g}$ to $9.40 \times 10^{5}$ $\mathrm{cfu} / \mathrm{g}$. Generally the microbial load of the selected fish samples was above WHO standard $\left(1.0 \times 10^{3} \mathrm{cfu} / \mathrm{g}\right)$. The intestine recorded the highest microbial load in all the samples (A-E) for the both serial dilution $\left(10^{-2}, \quad 10^{-}\right.$ ${ }^{3}$ ) followed by skin while the gills had the least microbial load.

Biochemical characterization from the fish samples: The result of the biochemical charact erization from the five fish samples in table 5 shows the presence of the following bacteria; Streptococcus species, Bacillus species, Staphylococcus aureus, Proteus mirabilis, Escherichia coli, Micrococcus species, Klebsiella pnueumonia, Pseudomonas species and Ser ratia species.

\section{Discussion}

The result revealed high microbial load above recommended safety standard from both water and fish samples. This may be attributed to anthropogenic activities such as washing, bathing,

Journal of the Faculty of Agriculture and Veterinary Medicine, Imo State University Owerri website: www ajol.info/index.php/jafs

Open Access article distributed under the terms of the Creative Commons License CC BY-NC 
Journal of Agriculture and Food Sciences

Amuneke, K.E., Igbodiegwu, G.C., Okeke, P. A.,

Volume 18, Number 1, April, 2020 pp 11 - 26

\& Adibe, A.C.

indiscriminate dumping of refuse, open defecation in and around the river and also flood from Otuocha market which empty into the river. The difference in the bacteria load of the five selected fish samples agrees with the fact that the presence of bacteria in natural aquatic ecosystem is dependent upon the rate of contamination and the equilibrium that is established between bacteria proliferation in that environment and the rate of their elimination (Lejeune et al., 2001). The total bacteria count in both fish and water samples were higher than that of WHO standard $\left(1.0 \times 10^{3} \mathrm{cfu} / 100 \mathrm{ml}\right)$. This may be because Otuocha people and marketers at Otuocha market use Otuocha river as dumping ground, for open defecation and due to lack of waste management and this study agrees with Atiribom and Kolndadacha (2014) that most people in this part of the world see rivers as dumping ground for every kind of wastes. The result shows that both water and fish samples contain pathogenic bacteria and this several researchers (Oyeleke and Istifanus, 2008., Raji and Ibrahim, 2011 and Novotny et al., 2004) had reported could cause water-food borne infection when ingested through contaminated water or food (fish). The result reported presence of human pathogens in water and fish samples. This agrees with Mitchell (1972) who states that freshwater fish may harbour human pathogens after exposure to contaminated water or food sources. The microbial loads were higher in fish samples than water sample. This could be due to some level of additional contamination by fishermen after the fish were caught probably due to unhygienic handling practices. Fish intestines harboured more bacteria load than the skin and gills of the selected five fish species examined. This corroborate with Kasing et al. (1999) who observed that the intestine of all fish examined harboured most number of bacteria species. Atiribom and Kolndadacha (2014) reported lower bacteria count compared to this study in both water and fish samples. They reported that the total bacteria count of water sample ranged from $1.2 \times 10^{2}$ to $1.4 \times 10^{3} \mathrm{cfu} / \mathrm{ml}$ which is low compared to this study. Similarly, they also reported that the total bacteria count of the intestine of sampled fish ranged from $3.5 \times 10^{3}$ to $3.1 \times 10^{4} \mathrm{cfu} / \mathrm{g}$. Such variation in total bacteria count could be associated with, diet, species of host animal and their physiological content (Sugita et al., 1998 Ajayi, et al., 2016). Bacteria flora of some freshwater fishes in the tropics shows that Aeronomnas species was most predominant microorganism isolated from the skin, gills and intestine of the fish which is contrary to the findings of this study which did not detect presence of Aeromonas species in either water or fish samples. The high level of microbes in the water and fish samples, from Otuocha river probably revealed the attitudes of Otuocha people and marketer at Otuocha market towards waste disposal and management. This agreed with the report of Dalgaard et al. (2006) that pollution of the aquatic habitats with faecal matter is mostly from human activities. The result reveals that both the fish and the water samples harboured microbes above WHO standard. This agreed with the opinion of Okonko et al. (2012) and Adebayo-Tayo et al. (2012b) that the microbial composition of fish depends upon the microbial counts of water in which they live. This study isolated different bacteria from both samples analysed. However, the presence of the pathogens in the fish samples could pose a potential public health threat to consumers. Fapohunda et al. (1994) and Velusamy et al. (2010) reported that pathogens such as Salmonella species, Staphylococcus species, Klebsiella species, Pseudomonas species and Escherichia coli are responsible for major food-borne outbreaks worldwide. Such organism should not be present on freshly-caught fish as opined by Chattopadhyay (2000). This finding

Journal of the Faculty of Agriculture and Veterinary Medicine, Imo State University Owerri website: www ajol.info/index.php/jafs

Open Access article distributed under the terms of the Creative Commons License CC BY-NC 
was in agreement with the findings by Gram and Dalgaard (2002), who reported that these organisms isolated were the major organism of freshly caught fish from polluted water. Most of the organisms isolated could cause food poisoning such as Shigellosis (Shigella species) and Salmonellosis (Salmonella species) as reported by Acha and Szyfres (2003). Also, enterotoxins produced by Staphylococcus aureus as opined by Vieira et al. (2001) are serious cause of gastroenteritis after consumption of fish and related products. The result reveals that sample D and C recorded the highest level of microbes; this scenario was similar with the findings of Ekeocha et al. (2017) who reported high microbial load in Protopterus annectens and Chrisitchyts nigrodigitatus. However, these they reported could be as a result of lipobacteria (fat loving bacteria) since these species are fatty fishes. Also, among the fish species, sample D harboured more bacteria than the rest of the fish species. This could be because it is a demersal species that feeds closer to the bottom where there is more organic matter in the sediment leading to a concomitant increase in the number of microbial flora. The occurrence of Bacillus species in both water and fish samples could be as a result of the prevalence of their spores in the environment. This was in agreement with the report of Robert (2010) that when fish are caught close to land, organisms of terrestrial origin mainly of the aerobic spore forming bacilli may be isolated. Bacillus species are implicated in causing a wide range of infectious diseases including abscesses, Bacteremia/Septicemia, wound and food borne infections, ear infections, endocarditis, meningitis, ophthalmitis, osteomyelitis peritonitis and respiratory and urinary infections (Morales et al., 2004). The presence of Staphylococcus aureus might have been through handling as it is a normal flora of the human skin (Okonta and Ekelemu, 2005). It could also be as a result of its prevalence in the environment especially in soil, plants, insects, animals, human and both fresh and brackish water. The pathogenicity of food-borne S. aureus is associated with the ability of some strains to produce enterotoxins. The presence of bacteria isolates in different fish samples analysed agrees with report of several researchers that the normal bacteria flora of fish is a direct reflection of the bacteria flora of the water which they swim (Horseley, 1973). Showell and Ama-Abasi (2015) reported that the difference in bacteria isolates observed among the different fish species may be explained by factors such as bacteria host specificity and food type (Eddy and Jone, 2002) and water resource (Verner -Jeffreys et al., 2003). Another reason for the variation in the quality of the flora could be antagonism among gut bacteria (Sun et al., 2008). Olafson (2001) and Vine et al. (2006) also reported that both marine and freshwater fish have been shown to have a specific indigenous gut microbiota and may change with fish age, nutritional status, and environmental conditions.

\section{CONCLUSION AND RECOMMENDATION}

The bacteriological analysis of Otuocha river reveals high load of bacteria in water and fish samples analysed and some of these bacteria are known to be pathogenic to both fish and humans. Therefore, it is apparent that greater attention must be given to the microflora of fish especially those of the gastro-intestinal tract and to the natural water body holding them since most of the fish consumed in Nigeria is purchased directly from the fishermen without passing through any health safety checks. It is recommended that fish caught from the Journal of the Faculty of Agriculture and Veterinary Medicine, Imo State University Owerri website: www ajol.info/index.php/jafs

Open Access article distributed under the terms of the Creative Commons License CC BY-NC 
Journal of Agriculture and Food Sciences

Amuneke, K.E., Igbodiegwu, G.C., Okeke, P. A.,

Volume 18, Number 1, April, 2020 pp $11-26$.

\& Adibe, A.C.

Otuocha river should be properly cooked or smoked before consumption to avoid zoonotic diseases. Also, sanitation within Otuocha market and its environs should be improved by the provision of public toilets and enactment of effective policy for the collection and disposal of waste in Otuocha especially in the market. Contamination of water bodies should be discouraged through public enlightenment.

Journal of the Faculty of Agriculture and Veterinary Medicine, Imo State University Owerri website: www ajol.info/index.php/jafs

Open Access article distributed under the terms of the Creative Commons License CC BY-NC 


\section{REFERENCES}

Abolagba, O.J and Melle, O.O. (2008). Chemical composition and keeping qualities of a scaly fish Tilapia (Oreochromis niloticus) smoked with two energy sources. African Journal of General Agriculture, 4(2): 113-117.

Acha, P.N. and Szyfres, B. (2003): Zoonoses and communicable diseases common to man and animals. Bacterioses and mycoses. $3^{\text {rd }}$ edition, Pan American Health Organization, Washington Dc, Scientific and technical publication No. 580, 378.

Adebayo-Tayo, B.C. Odu, N.N. Anyamele, L.M. Igwiloh, N.J. P.N. and Okonkwo, I.O. (2012a). Microbial quality of frozen fish sold in Uyo metropolis. Journal of Nature and Science, 10(3): 71-77.

Adebayo-Tayo, A.C. Odu, N.N. Michael, M.U. and Okonko, I.O. (2012). Multi-drug resistant (MDR) organism isolated from sea-foods in Uyo, south-southern region of Nigeria. Nature and science 10(3): 61-70.

Adebayo-Tayo, B.C. Odu, N.N. Igiwiloh, N.J. Okonko, I.O. (2012b). Microbiological and Physicochemical level of fresh catfish (Arius hendelotic) from different markets in Akwa Ibom state, Nigeria. New York Science Journal 5 (4):4652

Adebayo-Tayo, B.C. Onilude, A.A. Patrick, U.G. (2008): Mycoflora of smoke-dried fishes sold in Uyo, Eastern Nigeria. World Journal of Agriculture Science, 4 (3): 346-350.nble o

Adedeji, F.A. and Ibrahim, Z.B. (2013).Comparison of microbiological and proximate analysis of Synodontis nigrita, Chrysichthys nigrodigitatus and Mormyrus rume in Olomore Market, Abeokuta, Ogun State, Nigeria. In: Proceedings of the $28^{\text {th }}$ Annual Conference of Fisheries Society of Nigeria, 263-266.

Adedeji, O.B. Emikpe, B.O. and Adebisi, T. (2011). Bacteria load on the skin and stomach of Clarias gariepinus and Oreochromis niloticus from Ibadan, south west Nigeria: Public Health implications. Microbiology and Biotechnology Research, 1 (1): 5259.

Adedeji, O.B. Okerentugba, P.O. Innocent, D.E. Adiele, H.C. and Okonkwo, I.O (2012). Benefits, Public health hazards and risks associated with fish consumption. New York Science Journal 5: 33-61.

Adeyemo, O.K. (2003). Consequences of pollution and degradation of Nigeria aquatic environment fisheries resources. The Environmentalist 23 (4): 297-306.

Ajayi, O.T. Banjo, O.T. and Shonibare, O.F. (2016): Microbes prevalence in Clarias gariepinus and Oreochromis niloticus caught at Eleyele reservoir in Ibadan Nigeria. In: Proceedings of the $31^{\text {st }}$ Annual Conference of Fisheries Society of Nigeria, 125-129.

Aliyu, A. Ibrahim, Y.K.E. and Oyi, R.A. (2016). Bacteriological and elemental quality of Clarias gariepinus (Catfish) samples from river lavun, Bida Niger state, Nigeria. Nigeria Journal of Pharmaceutical Research. 12 (2):139-147.

Journal of the Faculty of Agriculture and Veterinary Medicine, Imo State University Owerri website: www ajol.info/index.php/jafs

Open Access article distributed under the terms of the Creative Commons License CC BY-NC 
American Public Health Association (1985). Standard method for the Examination of water and waste water. APHA and WPCVE, $16^{\text {th }}$ edition, Washington. D.C.

Atiribom, R. Y. and Kolndadacha, O. D. (2014). Assessment of the bacteriological profile of water and fish samples from Hadejia reservoir in Jigawa State. Trends in Applied Sciences Research, 9: 517-521.

Bergey, D. H. and Holt, J.G (1994). Bergey's manual of determinative bacteriology. Baltimore Williams $\&$ Wilkins, $9^{\text {th }}$ (Edition).

Chattopadhyay, P.(2000). Fish catching and handling. In: Robinson, R.K. (ed.): Encyclopedia of food microbiology. 2:1547 London: Academic press.

Cheesbrough, M. (1984). Medical laboratory manual for tropical countries. Cambridge University press, United Kingdom.

Clucas, I.J. and Ward. A.R. (1996). Post-Harvest fisheries development: A guide to handling, preservation, processing and quality. Natural Resources Institute., United Kingdom: Chatham Maritime. 665.

Dalgaard, P. Madsen, H.L. Samieian, N. Emborg, J. (2006). Biogenic amine formation and microbial spoilage in chilled garfish (Belone belone belone) - Effect of modified atmosphere packaging and previous frozen storage. Journal of Applied Microbiology 101(1):80-95.

Diler, O. Altun, S. Calikusu, F. and Diler, A. (2000). A study on qualitative and quantitative bacteria flora of the rainbow trout (Oncorhynchus mykiss) living in different farms. Turkish Journal of Veterinary Amount Sciences, 24: 251-259.

Eddy, S.D. and Jones, S.H. (2002). Microbiology of summer flounder, Paralichthys dentatus fingerling production in a marine fish hatchery. Aquaculture, 211:9-28.

Ekeocha, C.A. Agbabiaka, L.A. Onimisi, H.U. and Nnadi, E.A. (2017): Bacterial isolates from some freshwater fish species caught from Oguta lake Imo state, Nigeria. In: Proceedings of the $32^{\text {nd }}$ Annual Conference of Fisheries Society of Nigeria, 441-445

FAO (2002). Food and agricultural publication, year report (2002). FAO Rome 81-94.

FAO (2003). Assessment of management of seafood safety and quality. In: Food and Agriculture Organisation fisheries technical paper, 444, Rome, 230.

FAO (2012). The state of world fisheries and aquaculture. Rome Italy: Food and Agriculture Organisation of the United Nations.

Fapohunda, A.O. Macmillan, K.W. Marshall, D.L. and Waites, W.M. (1994). Growth of selected cross-contaminating bacterial pathogens on beef and fish at $150{ }^{\circ} \mathrm{C}$ and $350{ }^{\circ} \mathrm{C}$. Journal offood protection 57: 33740. 
FDA. (2011). Fish and fisheries products hazards and controls guidance. U.S.A: food and drug administration.

Gram, L. and Dalgaard, P. (2002). Fish spoilage bacteria problems and solution. Current Opinion in Biotechnology, 13, 262-266. https://doi.org/10.1016/S0958-1669(02)00309-9.

Horseley, R.W. (1973). The bacteria flora of the Atlantic salmon. Journal of applied Bacteriology, 36:377-86

Jacxsens, L. Kasuga, J. Luning, P.A. Van der Spiegel, M. Devlieghere, F. and Uyettendaele, M. (2009). A microbial assessment scheme to measure microbial performance of food safety management systems. International Journal of Food Microbiology, 134:11325.

Kabahenda, M.K. Omony, P. and Husken, S.M.C. (2009). Post-harvest handling of low-value fish products and threats to nutritional quality: a review of practices in the Lake Victoria region. Regional programme fisheries and HIV/AIDS in Africa: Investing in sustainable solutions. The worldfish center project report, 15.

Kasing, A. Asiah, M.V. and Kumbang, J. (1999). Distribution of bacteria in tropical freshwater fish and ponds. International Journal of Environmental Health Research. 9(4):285-292.

Lejeune, J. T. Besser, T. E. Rice, D. H. and Hancock, D. D. (2001). Methods for the isolation of water-borne Escherichia coli O157. Applied Microbiology., 32: 316-320.

Mitchell, R. (1972). Ecological control of microbial imbalances. In: Mitchell, R. (ed) water pollution microbiology. New York: Wiley Interscience, 273 - 288.

Morales, J. Moreno, J. Merino, S. Tomas, G. Martinez, J. and Garmamszegi (2004). Association between immune parameters, parasitism and stress in breeding pied flycatcher (Ficedula hypoleuca) females. Canadian Journal of Zoology 82(9): 1484-1492.

Novotny, L. Dvorska, L. Lorenkova, A. Beran, V.M and Pavlik, I. (2004). Fish: A potential source of bacterial pathogens for human beings. Veterinary Medicine Czech, 49 (9): 343358.

Okonko, I.O. Adedeji, O.B. Okerentugba, P.O. and Innocent-Adiele, H.C. (2012). Benefits, public health hazards and risk associated with fish consumption. New York Science Journal 5 (9): 33-61.

Okonko, I.O. Ogunjobi, A.A. Fajobi, E.A. Onoja, B.A. Babalola, E.T. and Adedeji, A.O. (2008). Comparative studies and microbial risk assessment of different ready-to-eat (RTE) frozen sea-foods processed in Ijora-Olopa, Lagos state, Nigeria. African Journal of Biotechnology 7 (16): 28982901.

Okonta, A.A. and Ekelemu, J.K. (2005). A preliminary study of micro-organisms associated with fish spoilage in Asaba, Nigeria. Proceedings of the $20^{\text {th }}$ Annual Conference of the Fisheries Society of Nigeria (FISON), Port Harcourt.

Journal of the Faculty of Agriculture and Veterinary Medicine, Imo State University Owerri website: www ajol.info/index.php/jafs

Open Access article distributed under the terms of the Creative Commons License CC BY-NC 
Olafson, J.A. (2001). Interactions between fish larvae and bacteria in marine aquaculture. Aquaculture, 200:223-247

Oyeleke, S.B. and Istifanus, N. (2008). The effects of Niger state Water treatment plant effluent on its receiving river kaduna. African Journal of Biotechnology, 7(10): 1530-1535.

Raji, M.I.O. and Ibrahim, Y.K.E. (2011). Prevalence of waterborne infections in northwest Nigeria: A retrospective Study. Journal of Public Health and Epidemiology, 3(8): 382385 .

Robert, B. (2010). Bacteria disease of fish. Animal Health and food safety laboratory system, University of California, USA

Sallam, K.I. (2007). Chemical, sensory and shelf life evaluation of sliced salmon treated with salts of organic acids. Food chemistry, 101 (2): 592600.

Showell, J.O. and Ama-Abasi, D.E. (2015). Microbial Load of commercially important fish species at cross river estuary, Nigeria. In: Proceedings of the $30^{\text {th }}$ annual conference of fisheries society of Nigeria, 245-247

Sugita, H. Hirose, Y. Matsuo, N and Deguchi, Y. (1998). Production of the antibacterial substance by Bascillus species strain NM12, an intestinal bacterium of Japanese costal fish. Aquaculture, 165: 269-280.

Sun, Y.Z. Mao, S.Y. Yao, W. and Zhu, W.Y. (2008). DGGE and 16s rDNA analysis reveals a highly diverse and rapidly colonizing bacterial community on different substrates in the rumen of goats. Animal, 2 (3): 391-398.

Velusamy, V. Arshak, K. Korostynska, O. Oliwa, K. and Adley, C. (2010). An overview of the food borne pathogen detection: In the perspective of biosensors. Biotechnology Advances, 28: 23254.

Verner-Jeffreys, D.W. Shields, R.J. and Bricknell, T.H. (2003). A comparison of the risk of surface water pollution by $E$. coli from feaces from grazing animals and from slurry disposal. Soil use management, 20 (1): 13-22

Vieira, R.H. Rodrigues, D.P. Gocalves, F.A. Menezes, F.G. Aragao, J.S. Sousa, O.V. (2001). Microbicidal effect of medicinal plant extracts (Psidium guajava Linn. and Carica papaya Linn.) upon bacteria isolated from fish muscles and known to induce Diarrhea in children. The Revista do Instituto de Medicina Tropical de São Paulo, 43: 14548.

Vine, N.G. Leukes, W.D. and Kaiser, H. (2006). Probiotics in marine larviculture. FEMS, Microbiology, 30:404-427.

Yagoub, S.O. (2009). Isolation of Enterobacteriaceae and Pseudomonas species. From raw fish market in Khartoum state. Journal of Bacteriology Research, 1 (7): 85-88

Journal of the Faculty of Agriculture and Veterinary Medicine, Imo State University Owerri website: www ajol.info/index.php/jafs

Open Access article distributed under the terms of the Creative Commons License CC BY-NC 
Journal of Agriculture and Food Sciences

Amuneke, K.E., Igbodiegwu, G.C., Okeke, P. A., 23

Volume 18, Number 1, April, 2020 pp 11 - 26.

\& Adibe, A.C.

\section{APPENDIX}

Table 1: Total bacteria count of water sample

Water sample

Total bacteria count $\left(10^{-1}\right)$

Total bacteria count $\left(\mathbf{1 0}^{-2}\right)$

Water sample

$1.72 \times 10^{4}$

$1.42 \times 10^{5}$

Table 2: Total coliform count

\begin{tabular}{llll}
\hline $\begin{array}{l}\text { Water } \\
\text { sample }\end{array}$ & $\begin{array}{l}\text { Number of colonies } \\
\text { on plate }\end{array}$ & $\begin{array}{l}\text { Number of colonies } \\
\text { per } \mathbf{1 0 0} \mathbf{~ m l}\end{array}$ & Nature of colonies \\
\hline Water sample & 32 & 64 & $\begin{array}{l}\text { Pink, without sheen } \\
\text { Pink, mucoid looking } \\
\text { colonies }\end{array}$ \\
& & & Colourless looking colonies
\end{tabular}

Journal of the Faculty of Agriculture and Veterinary Medicine, Imo State University Owerri website: www ajol.info/index.php/jafs

Open Access article distributed under the terms of the Creative Commons License CC BY-NC 
Table 3: Morphological and biochemical identification of the various isolates from the water sample

\begin{tabular}{|c|c|c|c|c|c|c|c|c|c|c|c|c|c|c|c|c|c|c|c|}
\hline Isolate & Form & Surface & Colour & Margin & Elevation & Opacity & Gram & Cat & Mot & Ind & MR & VP & Cit & Lac & Glu & Suc & Fru & Mal & Identity \\
\hline A & Circular & Smooth & White & Irregular & Flat & Rough & + & + & - & - & - & - & - & $\mathrm{AG}$ & $\mathrm{AG}$ & G & G & $\mathrm{G}$ & $\begin{array}{l}\text { Staphylococcus } \\
\text { epidermidis }\end{array}$ \\
\hline B & Circular & Smooth & $\begin{array}{l}\text { Yellowi } \\
\text { sh }\end{array}$ & Entire & Raised & Opaque & + & + & + & - & + & _ & - & $\mathrm{AG}$ & $\mathrm{AG}$ & G & $\mathrm{G}$ & $\mathrm{AG}$ & $\begin{array}{l}\text { Staphylococcus } \\
\text { aureus }\end{array}$ \\
\hline $\mathrm{C}$ & Circular & Shiny & White & Entire & Convex & Moist & - & + & + & - & - & + & + & $\mathrm{AG}$ & $\mathrm{AG}$ & $\mathrm{AG}$ & $\mathrm{AG}$ & $\mathrm{AG}$ & $\begin{array}{l}\text { Enterobacter } \\
\text { aerogenes }\end{array}$ \\
\hline D & Circular & Smooth & Cream & $\begin{array}{l}\text { Undulat } \\
\mathrm{e}\end{array}$ & Raised & Opaque & + & + & + & _ & - & + & + & - & G & - & G & $\mathrm{AG}$ & $\begin{array}{l}\text { Bacillus } \\
\text { species }\end{array}$ \\
\hline $\mathrm{E}$ & Circular & $\begin{array}{l}\text { Glisteni } \\
\mathrm{ng}\end{array}$ & Cream & Entire & Raised & $\begin{array}{l}\text { Transpar } \\
\text { ent }\end{array}$ & - & + & + & + & + & - & - & $\mathrm{AG}$ & $\mathrm{AG}$ & $\mathrm{AG}$ & $\mathrm{A}$ & $\mathrm{A}$ & $\begin{array}{l}\text { Escherichia } \\
\text { coli }\end{array}$ \\
\hline $\mathrm{F}$ & Circular & Smooth & Whitish & Entire & Convex & $\begin{array}{l}\text { Transluce } \\
\text { nt }\end{array}$ & - & + & + & - & - & - & + & $\mathrm{AG}$ & $\mathrm{AG}$ & A & $\mathrm{AG}$ & $\mathrm{AG}$ & $\begin{array}{l}\text { Pseudomonas } \\
\text { aeruginosa }\end{array}$ \\
\hline G & Irregular & $\begin{array}{l}\text { Glisteni } \\
\mathrm{ng}\end{array}$ & Cream & Entire & Raised & Opaque & _ & + & _ & - & + & _ & + & $\mathrm{AG}$ & $\mathrm{AG}$ & $\mathrm{AG}$ & $\mathrm{AG}$ & $\mathrm{AG}$ & $\begin{array}{l}\text { Klebsiella } \\
\text { pneumonie }\end{array}$ \\
\hline
\end{tabular}

Key: Gram: Gram reaction, Cat: Catalase test Mot: Motility test Ind: Indole test, MR: Methyl-red test VP: Voges-Proskauer test Cit: Citrate Utilization test

Sugar Fermentation Tests Lac: Lactose fermentation, Glu: Glucose fermentation, Suc: Sucrose fermentation, Fru: Fructose fermentation, Mal: Maltose fermentation, + : Positve, - : Negative, A: Acid production only, G: Gas production only, AG: Acid and Gas production 
Table 4: Total bacterial count of the fish samples

\begin{tabular}{lll}
\hline Sample & Total bacterial count $\left(10^{-2}\right)$ & Total bacterial count $\left(10^{-3}\right)$ \\
\hline A Skin & $2.14 \times 10^{5}$ & $1.48 \times 10^{6}$ \\
A Intestine & $2.64 \times 10^{5}$ & $1.96 \times 10^{6}$ \\
A Gills & $1.88 \times 10^{5}$ & $1.32 \times 10^{6}$ \\
B Skin & $2.32 \times 10^{5}$ & $1.88 \times 10^{6}$ \\
B Intestine & $2.46 \times 10^{5}$ & $2.00 \times 10^{6}$ \\
B Gills & $1.28 \times 10^{5}$ & $9.4 \times 10^{6}$ \\
C Skin & $2.20 \times 10^{5}$ & $1.84 \times 10^{6}$ \\
C Intestine & $2.48 \times 10^{5}$ & $2.00 \times 10^{6}$ \\
C Gills & $2.16 \times 10^{5}$ & $1.76 \times 10^{6}$ \\
D Skin & $2.60 \times 10^{5}$ & $1.96 \times 10^{6}$ \\
D Intestine & $2.84 \times 10^{5}$ & $2.04 \times 10^{6}$ \\
D Gills & $1.88 \times 10^{5}$ & $1.44 \times 10^{6}$ \\
E Skin & $2.08 \times 10^{5}$ & $1.72 \times 10^{6}$ \\
E Intestine & $2.30 \times 10^{5}$ & $1.98 \times 10^{6}$ \\
E Gills & $1.94 \times 10^{5}$ & $1.68 \times 10^{6}$ \\
\hline & & \\
\hline
\end{tabular}


Table 5: Properties and identity of the bacterial isolated from fish sample

\begin{tabular}{|c|c|c|c|c|c|c|c|c|c|c|c|c|c|}
\hline$\underset{\frac{\pi}{\pi}}{0}$ & 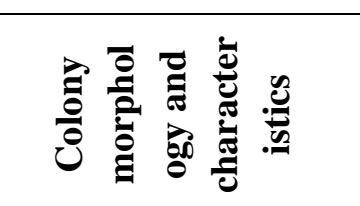 & 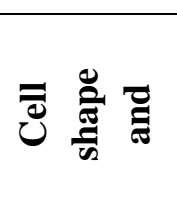 & 莺 & $\frac{\ddot{E}}{\frac{\mathscr{E}}{\pi}}$ & ن & 苛 & $\sum_{\bar{E}}^{\bar{a}}$ & $\stackrel{\frac{0}{0}}{\Xi}$ & $\stackrel{\leftrightarrow}{\longrightarrow}$ & 总 & 芯 & $\frac{\mathscr{D}}{\mathscr{E}}$ & 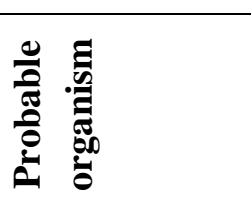 \\
\hline A & $\begin{array}{l}\text { Large colonies, } \\
\text { cream to yellowish on } \\
\text { nutrient agar }\end{array}$ & $\begin{array}{l}\text { Gram } \\
\text { positive } \\
\text { cocci in } \\
\text { chains }\end{array}$ & + & - & - & - & - & - & - & A+ & - & $\mathrm{G}+$ & $\begin{array}{l}\text { Streptococcus } \\
\text { species }\end{array}$ \\
\hline B & $\begin{array}{l}\text { Whitish medium sized } \\
\text { mucoid colonies on } \\
\text { nutrient agar }\end{array}$ & $\begin{array}{l}\text { Gram } \\
\text { positive } \\
\text { long } \\
\text { rods }\end{array}$ & + & + & + & + & - & - & - & - & - & - & $\begin{array}{l}\text { Bacillus } \\
\text { species }\end{array}$ \\
\hline $\mathrm{C}$ & $\begin{array}{l}\text { Large colonies, } \\
\text { cream to yellowish on } \\
\text { nutrient agar }\end{array}$ & $\begin{array}{l}\text { Gram } \\
\text { positive } \\
\text { cocci in } \\
\text { clusters }\end{array}$ & + & + & + & - & - & - & - & $\mathrm{AG}+$ & $\mathrm{AG}+$ & $\begin{array}{l}\mathrm{AG} \\
+\end{array}$ & $\begin{array}{l}\text { Staphylococcu } \\
\text { s aureus }\end{array}$ \\
\hline D & $\begin{array}{l}\text { Whitish colonies on } \\
\text { nutrient agar }\end{array}$ & $\begin{array}{l}\text { Gram } \\
\text { negative } \\
\text { rods }\end{array}$ & + & + & + & - & - & - & - & AG+ & - & $\begin{array}{l}\mathrm{AG} \\
+\end{array}$ & $\begin{array}{l}\text { Proteus } \\
\text { mirabilis }\end{array}$ \\
\hline $\mathrm{E}$ & $\begin{array}{l}\text { Grey medium } \\
\text { colonies on nutrient } \\
\text { agar }\end{array}$ & $\begin{array}{l}\text { Gram } \\
\text { negative } \\
\text { rods }\end{array}$ & + & + & - & - & + & + & - & AG+ & $\mathrm{AG}+$ & $\begin{array}{l}\mathrm{AG} \\
+\end{array}$ & $\begin{array}{l}\text { Escherichia } \\
\text { coli }\end{array}$ \\
\hline F & $\begin{array}{l}\text { Large colonies, } \\
\text { Creamy to yellowish } \\
\text { on nutrient agar }\end{array}$ & $\begin{array}{l}\text { Gram } \\
\text { positive } \\
\text { cocci }\end{array}$ & + & + & + & + & + & + & + & $\mathrm{AG}+$ & $\mathrm{AG}+$ & $\begin{array}{l}\mathrm{AG} \\
+\end{array}$ & $\begin{array}{l}\text { Micrococcus } \\
\text { species }\end{array}$ \\
\hline G & $\begin{array}{l}\text { Medium to large } \\
\text { Grey mucoid colonies }\end{array}$ & $\begin{array}{l}\text { Gram } \\
\text { negative } \\
\text { short } \\
\text { rods }\end{array}$ & - & + & - & + & - & - & + & $\mathrm{AG}+$ & $\mathrm{AG}+$ & $\begin{array}{l}\mathrm{AG} \\
+\end{array}$ & $\begin{array}{l}\text { Klebsiella } \\
\text { pneumonia }\end{array}$ \\
\hline $\mathrm{H}$ & $\begin{array}{l}\text { Medium to large } \\
\text { grey mucoid } \\
\text { colonies }\end{array}$ & $\begin{array}{l}\text { Gram } \\
\text { negative } \\
\text { short } \\
\text { rods }\end{array}$ & + & + & - & + & - & - & - & - & - & - & $\begin{array}{l}\text { Pseudomonas } \\
\text { species }\end{array}$ \\
\hline I & $\begin{array}{l}\text { Whitish colonies on } \\
\text { nutrient agar }\end{array}$ & $\begin{array}{l}\text { Gram } \\
\text { negative } \\
\text { rods }\end{array}$ & + & - & - & + & + & - & - & $\mathrm{G}+$ & - & - & $\begin{array}{l}\text { Serratia } \\
\text { species }\end{array}$ \\
\hline
\end{tabular}

Keys: + Positive; - Negative; A+ Positive and Acid produced; AG+ Positive and produces both Acid and Gas; G+ Gas production only 